\title{
Studi Karakteristik Pembangkit Listrik Thermoelektrik Melalui Pemanfaatan Panas Knalpot Sepeda Motor Sport 150 cc.
}

\author{
Wardoyo \\ DosenTeknik Mesin Universitas Negeri Jakarta \\ Wardoyo-mt@yahoo.co.id
}

\begin{abstract}
ABSTRAK
Polusi pada kendaraan bermotor dihasilkan dari sisa hasil pembakaran pada mesin yaitu berupa gas. Gas buang pada kendaraan bermotor memiliki kandungan energi panas, energi panas yang terkandung dalam gas buang tergantung dari banyaknya putaran mesin. Semakin banyak putaran mesin maka panas yang dihasilkan dari gas buang akan semakin besar. Gas buang pada kendaraan bermotor dikeluarkan melalui knlapot sehingga komponen ini memiliki suhu paling tinggi saat sepeda motor bergerak. Panas fluida pada knalpot pada sepeda motor dapat mencapai lebih dari 3000c. Pada kesempatan ini telah diteliti karakteristik pembangkit listrik termoelektrik melalui pemanfaatan panas knalpot sport 150 cc dengan pendingin berbentuk slot fin .

Karakteristik pembangkitan listrik oleh termoelektrik diuji besar daya yang dihasilkan pada kondisi temperatur yang berbeda. Penelitian ini menggunakan delapan sensor termokopel untuk mengukur karakteristik termal yang terjadi dan Avometer untuk mengukur tegangan dan arus yang dihasilkan. Pengambilan data dilakukan pada kecepatan udara melewati kendaraan $4,7 \mathrm{~m} / \mathrm{s}, 5,7 \mathrm{~m} / \mathrm{s}$ dan $7,2 \mathrm{~m} / \mathrm{s}$ yang disimulasikan dengan menggunakan fan, dan variabel putaran mesin 2000 rpm, 2500 rpm, 3000 rpm, 3500 rpm dan $4000 \mathrm{rpm}$.

Hasil penelitian ini menunjukan daya terbesar yang diperoleh 36,15 Watt pada putaran mesin 4000 rpm dan kecepatan angin 7,2 m/s. Pengaruh putaran mesin lebih dominan dari pada kecepatan angin, peningkatan daya terbesar terjadi pada putaran mesin antara $2000 \mathrm{rpm}-2500 \mathrm{rpm}$. Termoelektrik yang digunakan tipe refrigerator sehingga tidak tahan pada temperatur tinggi, pada saat mencapai termperatur tertentu kinerjanya mulai turun. Pada penelitian sejenis akan lebih baik jika menggunakan termoelektrik tipe generator.
\end{abstract}

Kata Kunci : termolektrik, pembangkit listrik, sirip pendingin, tegangan, arus

\section{Pendahuluan}

1.1. Latar Belakang

Efek pemanasan global yang mulai terasa dalam tahun-tahun terakhir ini, membuat kesadaran masyarakat dunia untuk mencari solusi terhadap pencemaran udara yang disebabkan oleh alat-alat/komponen pabrik/industri serta kendaraan yang tidak ramah lingkungan.

Semakin bertambahnya jumlah dan jenis kendaraan yang beredar di masyarakat membuat pemanasan di bumi semakin menjadi. Khususnya sepeda motor yang semakin diminati di negeri ini turut menyumbang pemanasan pada bumi.
Archie (1996) dengan berpatokan pada 3E, yaitu energi, ekonomi dan ekologi berbagai penemuan konversi energi tepat guna ditemukan. Intinya harus bisa memanfaatkan energi semaksimal mungkin yang terbuang, dengan biaya yang rendah serta mempunyai dampak minimal terhadap lingkungan.[1]

Pada kendaraan bermotor terdapat energi panas yang terbuang dari hasil pembakaran dalam ruang bakar. Jika panas ini tidak dimanfaatkan maka akan terbuang begitu saja ke atmosfer dan akan menjadi polusi termal. Saat ini panas mesin yang terbuang melalui knalpot dibiarkan begitu saja dan belum banyak dimanfaatkan. Cara yang dianggap paling praktis dan 
memungkinkan diproduksi secara komersial adalah mengubahnya menjadi energi listrik.

Pemanfaatan energi panas yang terbuang pada knalpot kendaraan bermotor diubah menjadi energi listrik, metode paling sederhana dengan menggunakan konsep Seebeck. Apabila terdapat dua sumber temperatur yang berbeda pada dua material semi konduktor maka akan mengalir arus listrik pada material tersebut. Konsep ini lebih dikenal dengan pembangkit termoelektrik.

Dengan mengacu pada prinsip perbedaan temperatur yang dihasilkan, jika semakin besar beda temperatur $(\Delta \mathrm{T})$ maka akan menghasilkan daya yang besar pada termoelektrik untuk itu dibutuhkan pelepas panas yang mampu bekerja secara efektif. Yuninto (2010) membandingkan pelepas panas bentuk extrude dan slot, menyimpulkan bahwa panas yang dilepas lebih efektif pada desain pelepas panas bentuk slot.

Pada kesempatan ini telah diteliti karakteristik pembangkit listrik termoelektrik melalui pemanfaatan panas knalpot sport 150 cc dengan pendingin berbentuk slot fin.

\subsection{Tujuan Penelitian}

Penelitian ini bertujuan untuk menyelidiki karakteristik pembangkit listrik termoelektrik melalui pemanfaatan panas knalpot sepeda motor sport $150 \mathrm{cc}$ dengan pendingin berbentuk slot fin.

Hasil penelitian ini diharapkan dapat menjadi sumbangan pemikiran bagi ilmu pengetahuan serta dapat memberi informasi seluas-luasnya kepada masyarakat tentang metode pemanfaatan panas gas buang menjadi energi alternatif melalui efek Seebeck dengan menggunakan termoelektrik.

\section{Tinjuan Pustaka}

Energi adalah kemampuan untuk melakukan usaha. Pernyataan hukum pertama termodinamika tentang kekekalan energy, energi bersifat kekal, energi tidak dapat diciptakan dan tidak dapat dimusnahkan, tetapi dapat dikonversi dari bentuk energi yang satu ke bentuk energi yang lain.

Albert Einstein membuat hipotesis bahwa energi sebenarnya dihubungkan dengan persamaan berikut:

$$
\mathrm{E}=m c^{2}
$$

Dimana E adalah energi yang dilepaskan, dalam joule, $\mathrm{m}$ adalah massa sebenarnya yang dikonversi menjadi energi dalam kilogram, dan c adalah kecepatan cahaya $\left(3 \times 10^{8} \mathrm{~m} / \mathrm{det}\right)$

\subsection{Dasar Konversi Energi}

Sumber-sumber energi bisa dikelompokkan dalam dua kategori secara umum. Energi celestial dan energi modal. Energi celestial atau energi perolehan yakni energi yang mencapai bumi dari luar angkasa. Energi yang termasuk dalam energi celestial adalah energi surya. Kelebihan energi ini adalah tak pernah habis dan bebas polusi. Sedangkan energi modal adalah energi yang sudah ada sejak lama di dalam bumi, energi yang termasuk di dalamnya adalah energi atom serta energi geotermal.

Energi yang paling mudah untuk dikonversikan ke beberapa bentuk energy adalah energi listrik. Selain itu energi listrik dapat dihasilkan langsung dari berbagai bentuk energi tanpa harus melewati bentuk perantara energi lainnya. Maka dari itulah energi listrik sering disebut sebagai direct energy converter.

Terdapat banyak aplikasi konversi yang dapat dilakukan untuk memproduksi energi listrik, seperti; konversi energi termal menjadi energi listrik, proses konversi energi sperti ini biasanya menggunakan konsep Seebeck dengan memanfaatkan termoelektrik. 


\subsection{Termoelektrik}

Sebenarnya efek termoelektrik ini adalah penemuan lama yang baru menjadi perbincangan serius ketika sumber energi di bumi mulai habis. Bila berbicara temoelektrik, maka kita tidak bisa lepas dari teori efek Peltier, efek Seeback dan efek Thomson. Karena ketiga teori ini adalah teori dasar dari termoelektrik.

Fenomena termoelektrik ini pertama kali ditemukan oleh Thomas Johan Seebeck pada tahun 1821. Menurut Seebeck bahwa sebuah voltase timbul dalam sirkuit dua material yang tidak sama jika kedua simpangan ini dijaga pada temperatur yang berbeda.

Masih berkaitan dengan efek Seebeck di buku lainnya menjelaskan bahwa efek Seebeck timbul karena kerapatan muatan pembawa elektron dalam logam suatu penghantar berbeda dengan penghantar lainnya tergantung pada temperatur.

Untuk mengetahui besaran dari Seebeck maka harus mengetahui koefisien Seebeck. Koefisien Seebeck adalah sifat material dalam memberikan kecepatan perubahan potensial termoelektrik Es dengan suhu T.

$$
S=\frac{\mathrm{dE}_{\mathrm{S}}}{\mathrm{dT}}
$$

Kemudian beberapa tahun setelahnya, seorang peneliti, Jean Charles Peltier di tahun 1844 mendalami teori dari Seebeck. Dia mengalirkan listrik pada dua buah logam yang direkatkan dalam sebuah rangkaian. Ketika arus dialirkan, terjadi penyerapan panas pada sambungan kedua logam dan pelepasan panas di sambungan lainnya. Pelepasan panas ini bisa berbalik ketika arah arus juga ikut dibalik.

Koefisien Peltier untuk suatu rangkaian yang terdiri dari material A dan $\mathrm{B}$ ditandai dengan $\pi$ ab didefinisikan sebagai

$$
\pi \mathrm{ab}=\frac{-\mathrm{Q}}{\mathrm{i}_{\mathrm{ab}}}
$$

Dimana $-\mathrm{Q}$ adalah jumlah perpindahan kalor dari persimpangan dalam watt, dan iab adalah arus searah yang mengalir di dalam generator dalam ampere.

Dari hasil kedua penelitian ini, Seebeck dan Peltier pun menjadi dasar dari pengembangan teknologi termoelektrik saat ini. Karena saling berhubungan, maka kedua persamaan di atas memiliki hubungan sebagai berikut:

$\pi \mathrm{ab}=\mathrm{T}(\mathrm{L}$ atau $\mathrm{H}) \mathrm{Sab}=\mathrm{T}(\mathrm{L}$ atau $\mathrm{H})(\mathrm{Sa}-\mathrm{Sb})=$ $-\pi \mathrm{ba}$

\subsection{Modul Termoelektrik}

Modul termoelektrik Peltier umumnya dibungkus oleh keramik tipis yang berisikan batang-batang Bismuth Telluride di dalamnya.

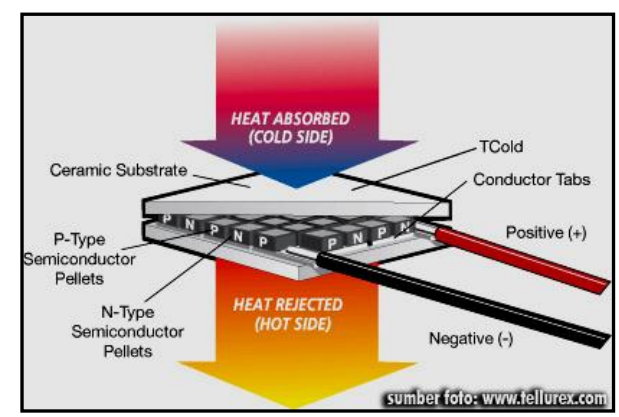

Gambar -1. Modul termoelektrik

Gambar di atas adalah skema kerja sederhana dari modul termoelektrik. Sesuai dengan efek Seebeck bahwa perbedaan temperatur antara penghantar akan menghasilkan arus listrik. Jika kedua konduktor dibiarkan mencapai kesetimbangan termodinamika, proses ini akan menghasilkan panas yang didistribusikan secara merata sepanjang konduktor tersebut.

Semikonduktor n-p biasa digunakan dalam sistem-sistem termoelektrik (gambar2). karena dikehendaki konduktivitas atau konduktansi panas yang rendah, biasa dipakai 
material yang mempunyai berat atom atau berat molekul yang tinggi karena mempunyai konduktivitas yang rendah.

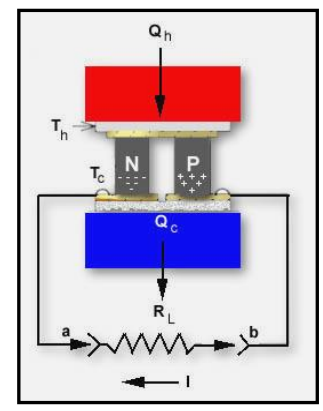

Gambar -2. Skema kerja termoelektrik sederhana

Nilai efesiensi (ZT) dari beberapa material termoelektrik yang ditunjukkan dalam gambar-3 untuk kedua material n-p. Timah tellurida (PbTe) biasa dipakai dalam generator termoelektrik sedangkan Bismuth tellurida (Bi2Te) biasa dipakai dalam refrigerator termoelektrik.

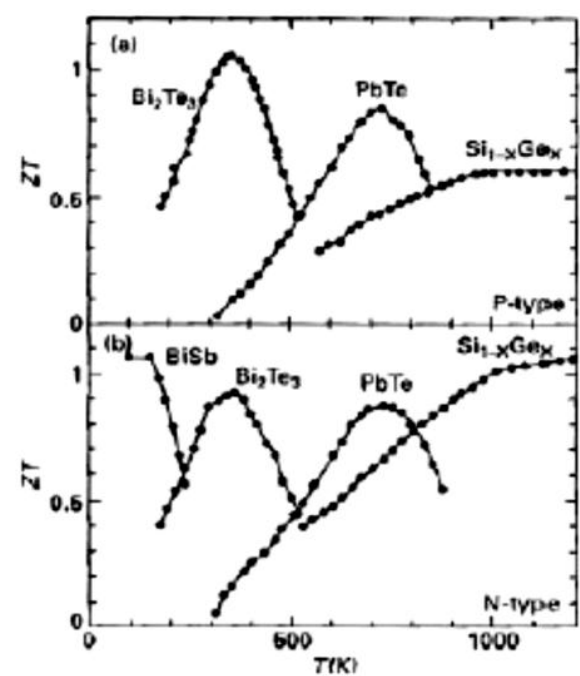

Gambar -3. Grafik sifat-sifat beberapa jenis material termoelektrik
2.4. Termoelektrik

Refrigerator termoelektrik

Selain sebagai pembangkit listrik, sistem termoelektrik juga dapat dipakai sebagai pemindah panas atau refrigerator. Jika digunakan sebagai refrigerator termoelektrik, arus searah dialirkan melalui unit, dan satu sisi dipanaskan sementara sisi yang lain didinginkan. Pembalikan dari sistem termoelektrik ini pun juga memungkinkan.

\section{Metode Penelitian}

Bahan dan alat yang digunakan dalam penelitian ini, antara lain :

a. Aluminium profil

b. Heatsink (Pelepas panas) yang telah dimodifikasi menjadi model slot

c. Delapan Modul Termoelektrik (TEC112706)

\begin{tabular}{|l|c|c|}
\hline Hot Side Temperature $\left({ }^{\circ} \mathrm{C}\right.$ ) & $25^{\circ} \mathrm{C}$ & $50^{\circ} \mathrm{C}$ \\
\hline Qmax (Watts) & 50 & 57 \\
\hline Delta Tmax $\left({ }^{\circ} \mathrm{C}\right.$ ) & 66 & 75 \\
\hline Imax (Amps) & 6.4 & 6.4 \\
\hline Vmax (Volts) & 14.4 & 16.4 \\
\hline Module Resistance (Ohms) & 1.98 & 2.30 \\
\hline
\end{tabular}

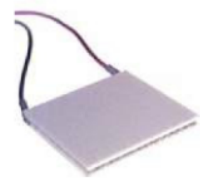

Gambar -4. Termoelektrik (TEC1-12706)

d. Alat ukur: Multimeter sebagai pengukur arus dan tegangan listrik, Termokopel Tipe-k sebagai sensor temperatur dan Anemometer sebagai pengukur kecepatan angin,

e. Kipas angin sebagai simulator angin yang diterima slot fin pada saat motor berjalan,

f. Sepeda motor sport $150 \mathrm{cc}$,

g. Pasta termal sebagai penghantar panas antara TEC dengan Aluminium

Untuk mengetahui karakteristik pembangkitan listrik pada termoelektrik dan kondisi temperatur di beberapa titik pada sumber panas dan pendingin dipasang beberapa termokopel, seperti gambar berikut ini. 


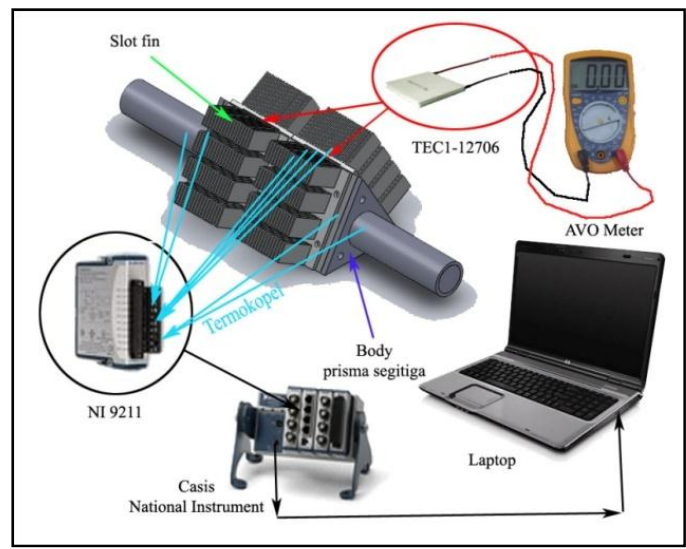

Gambar -5. Skema instalasi pengujian alat.

Karakteristik pembangkitan listrik oleh termoelektrik ini diuji seberapa besar daya yang dihasilkan pada beberapa kondisi temperatur yang berbeda. Penelitian ini menggunakan delapan sensor termokopel untuk mengukur karakteristik termal yang terjadi dan Avometer untuk mengukur tegangan dan arus yang dihasilkan.

Pengambilan data dilakukan pada kecepatan udara melewati kendaraan $4,7 \mathrm{~m} / \mathrm{s}$, $5,7 \mathrm{~m} / \mathrm{s}$ dan $7,2 \mathrm{~m} / \mathrm{s}$ yang disimulasikan dengan menggunakan fan dan variabel putaran mesin $2000 \mathrm{rpm}, 2500 \mathrm{rpm}, 3000$ rpm, $3500 \mathrm{rpm}$ dan $4000 \mathrm{rpm}$.

\section{Hasil Penelitian}

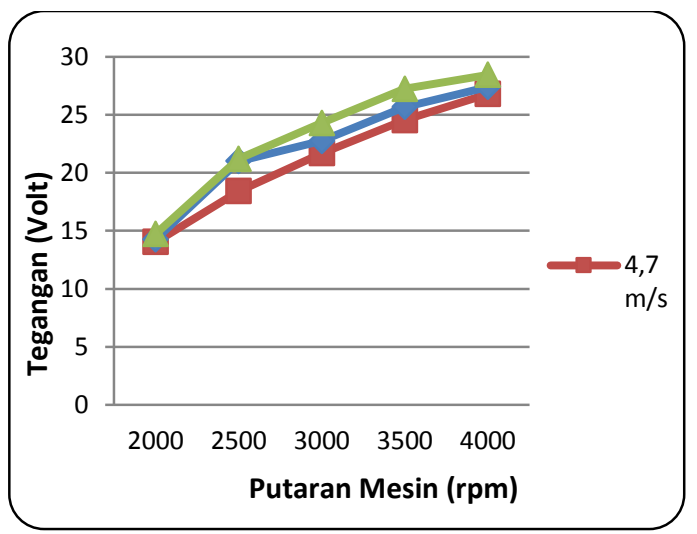

Gambar - 6. Grafik pengaruh putaran mesin terhadap tegangan terhadap putaran mesin
Dari gambar - 6 terlihat grafik pengaruh putaran mesin terhadap tegangan yang dihasilkan termoelektrik, grafik tersebut menunjukan karakteristik tegangan cenderung meningkat seiring dengan meningkatnya putaran mesin. Dengan naiknya putaran mesin maka panas yang dihasilkan knalpot akan meningkat sehingga terjadi perbedaan temperatur yang lebih besar pada kedua permukaan termoelektrik. Pada saat kecepatan angin melewati kendaraan meningkat, arus yang dihasilkan cederung meningkat seiring dengan meningkatnya proses pendinginan sirip pendingin.

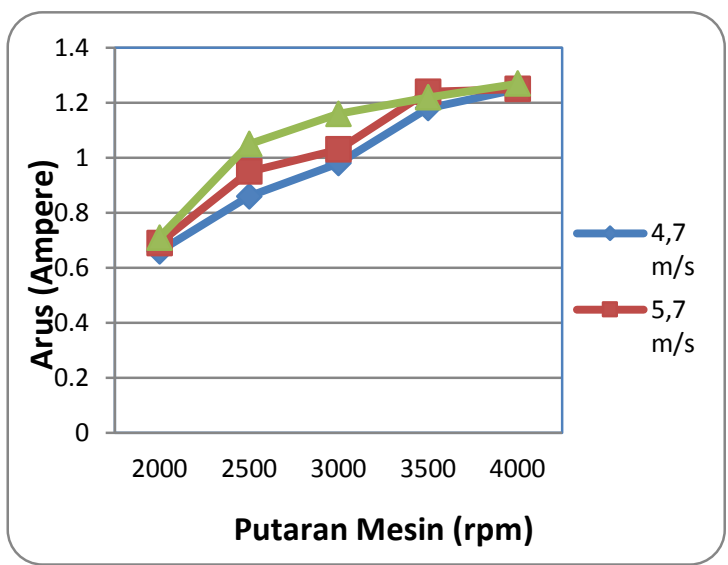

Gambar - 7. Grafik pengaruh putaran mesin terhadap arus

Pada gambar - 7 terlihat grafik kuat arus yang dihasilkan termoelektrik memiliki tren yang serupa dengan grafik tegangan. Peningkatan signifikan terjadi pada putaran mesin $2000 \mathrm{rpm}$ - $2500 \mathrm{rpm}$. Sementara pada putaran di atas $2500 \mathrm{rpm}$ hanya mengalami sedikit peningkatan. Hal ini desebabkan performa termoelektrik sudah mulai turun. Termoelektrik yang digunakan tipe refrigerator sehingga tidak tahan pada temperatur tinggi, pada saat mencapai termperatur tertentu kinerjanya mulai turun, pada saat mencapai titik klimaksnya termoelektrik akan rusak. Pada penelitian ini beberapa kali mengganti termoelektrik. Termoelektrik tipe ini dipilih karena harganya terjangkau. 


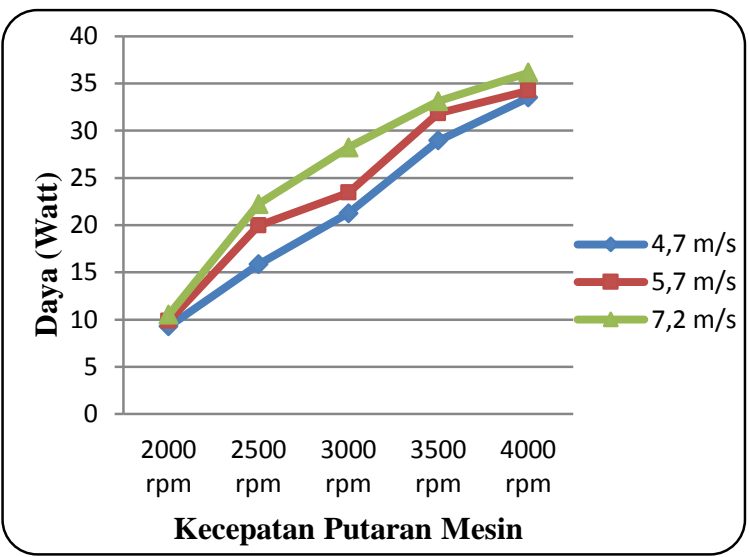

Gambar - 8. Grafik pengaruh putaran mesin terhadap daya

Karakteristik grafik daya merupakan perpaduan antara tegangan dan kuat arus yang dihasilkan oleh termoelektrik. Pada grafik - 8 terlihat dengan meningkatnya putaran mesin dan kecepatan angin yang melalui kendaraan, daya yang dihasilkan akan cendarung meningkat. Pengaruh putaran mesin lebih dominan dari pada kecepatan angin. Peningkatan terbesar terjadi pada putaran mesin antara $2000 \mathrm{rpm}-2500$ rpm.

\section{Kesimpulan}

Daya terbesar yang diperoleh 36,15 Watt pada putaran mesin $4000 \mathrm{rpm}$ dan kecepatan angin 7,2 m/s.

Pengaruh putaran mesin lebih dominan dari pada kecepatan angin, peningkatan terbesar terjadi pada putaran mesin antara $2000 \mathrm{rpm}-2500 \mathrm{rpm}$.

Termoelektrik yang digunakan tipe refrigerator sehingga tidak tahan pada temperatur tinggi, pada saat mencapai termperatur tertentu kinerjanya mulai turun.

Pada penelitian sejenis akan lebih baik jika menggunakan termoelektrik tipe generator.

\section{DAFTAR PUSTAKA}

[1]. Incropera, Frank. P (1981). Fundamental of Heat Transfer. Jhon Willey \& Son. Inc, Canada.

[2]. James R.Welty dkk (2004). Dasar-dasar Fenomena Transport ; volume 2 transfer panas, Terjemahan: Gunawan Prasetio, Edisi keempat, Jakarta: Erlangga

[3]. Koestoer, Raldi Artono (2002). Perpindahan Kalor Untuk Teknik Mesin, Jakarta: Salemba Teknik.

[4]. Kreith, Frank (1997). Prinsip-prinsip Perpindahan Panas, Terjemahan: Arko Prijono, Edisi ketiga, Jakarta: Erlangga

[5]. Mark W. Zemansky., and Richard H. Dittman (1986). Kalor dan Termodinamika Terjemahan: Suroso, Bandung: Penerbit ITB,.

[6]. Nandy Putra, R.A Koestoer, M. Adhitya, Ardian Roekettino, Bayu Trianto (2009). Potensi Pembangkit Daya Termoelektrik Untuk Kendaraan Hibrid. Makara. Teknologi, Vol.13, No.2, Jakarta: FTUI, h.53-56

[7]. Suyatmo, F (1996). Dasar-dasar Teknik Listrik, Jakarta: Rineka cipta.

[8]. Supriatna, Yayat (1999). Listrik Otomotif, Bandung: Angkasa.

[9]. Tipler, Paul (1998). Fisika untuk Sains dan Teknik, Jakarta: Erlangga.

[10]. W. Culp, Archie (1996). Prinsipprinsip Konversi Energi, Jakarta: Erlangga. 